\title{
PENGARUH LAYANAN BIMBINGAN KELOMPOK TERHADAP KEMANDIRIAN BELAJAR SISWA
}

Oleh:

\author{
Aisyah Amini Maladani ${ }^{1}$, Sudarmi Suud Binasar ${ }^{2)}$ \\ 1) 2) Jurusan Bimbingan dan Konseling \\ Fakultas Keguruan dan Ilmu Pendidikan, Universitas Halu Oleo \\ Email: aminimaladani22@gmail.com
}

\begin{abstract}
ABSTRAK
Tujuan Penelitian ini untuk mengetahui pengaruh layanan bimbingan kelompok terhadap kemandirian belajar siswa SMP Negeri 1 Bondoala. Jenis penelitian ini adalah Pra eksperimen dengan desain One Group Pre Test and Post Test. Subjek penelitian sebanyak 8 siswa. Tehnik pengumpulan data menggunakan angket kemandirian belajar. Hasil penelitian sebelum diberikan layanan bimbingan kelompok siswa memiliki kecenderungan kemandirian belajar rendah dengan perolehan rata rata $60,88 \%$. Sedangkan setelah diberi perlakuan kemandirian belajar siswa meningkat sebanyak $17,62 \%$ dengan perolehan skor rata-rata 78,5\%. Kesimpulan: hasil analisis inferensial dengan menggunakan uji wicolxon signed rank dengan taraf signifikansi $\alpha=0,05$ dan diperoleh $\mathrm{P}_{\text {value }}=0,005$. Oleh karena itu $\mathrm{P}_{\text {value }} \alpha$ $(0,005<0,05)$ maka Ho ditolak, sehingga layanan bimbingan kelompok berpengaruh terhadap kemandirian belajar siswa SMP Negeri 1 Bondoala
\end{abstract}

Kata Kunci: Kemandirian Belajar, Bimbingan kelompok

THE EFFECT OF GROUP GUIDANCE SERVICE ON STUDENTS INDEPENDENT LEARNING

\begin{abstract}
The objective of the research was to find out the effect of group guidance service on the students independent learning of Public High School (SMP) 1 Bondoala. The subjects of the research were 8 students. This was pre experimentalresearch with one group pre test and post test design. The data were collected through questionnaires on independent learning. Before the students have been provided with group guidance service, the students' independents learning are in low category. The students' average scores are $60,88 \%$. However, after the students have been provided with group guidance service, their independents learning are improving to $17,62 \%$. The students average scores are 78,5\%. Based on the result of inferential analyses test using Wilcoxon Signed Rank Test, it was found that it's significant was $a=0,05$ with its Pvalue $=0.005$. In other words, the Pvalue $<a(0.005<0.05)$. The test result indicates that Ho is rejected. The finding can therefore be concluded that group guidance services have effects on the students independent learning of the Public High School (SMP) 1 Bondoala.
\end{abstract}

Keywords: Independent Learning, Group Guidance 


\section{Pendahuluan}

Kemandirian merupakan hal yang sangat penting yang harus dimiliki oleh setiap individu terutama bagi siswa sebagai pembelajar. Salah satu tolok ukur untuk mencapai suatu keberhasilan belajar adalah dengan adanya sikap mandiri. Sriyono (2015: 22) mengemukakan kemandirian belajar yaitu adanya aktifitas belajar yang diatur oleh diri sendiri, kesadaran diri dan bersifat mandiri, atau mengatur kebutuhan sendiri tanpa bergantung pada orang lain sebagai sumber belajar dalam menyelesaikan permasalahan belajarnya.

Setiap siswa memiliki tingkat kemandirian yang berbeda-beda, dimana siswa yang sudah terbiasa mandiri cenderung tidak akan mengalami kesulitan dalam belajar karena siswa sudah mampu untuk mengatur dan mengarahkan dirinya sendiri sehingga siswa mampu menunjukkan kesiapan dalam belajar dan lebih mandiri dalam belajar. Sedangkan siswa yang kemandirian belajarnya rendah cenderung akan mengalami kesulitan dalam belajar, dimana siswa yang kemandirian belajarnya rendah akan sulit dalam mengatur dan mengarahkan dirinya serta tidak memiliki tanggung jawab dan mengandalkan orang lain dalam menyelesaikan setiap masalah belajar yang dihadapinnya. Sikap mandiri tidak akan dimiliki siswa dengan cepat, tetapi harus membutuhkan kesadaran diri, kebiasaan dan latihan kedisiplinan yang bertahap.

Hal tersebut sejalan dengan yang diungkapkan Sanan dan Yamin (dalam Moerdiyanto, 2014: 50) bahwa belajar mandiri adalah bentuk belajar yang memiliki kesadaran tinggi untuk melakukan kegiatan belajar tanpa diperintah oleh orang lain, penuh keyakinan, memiliki rasa tanggung jawab yang tinggi terhadap setiap keputusan dan tindakan yang diambil oleh setiap individu, menghargai waktu dan percaya akan kemampuan diri dalam menyelesaikan segala permasalahan belajar, tanpa adanya dorongan dari orang lain melainkan dari motivasi instriksirnya sendiri.

Siswa yang mandiri dalam belajar juga tidak akan tercipta apabila masih ada kebiasaan tergantung pada orang lain. Siswa akan mandiri dalam belajar apabila siswa sadar akan pentingnya belajar dalam kehidupanya. Siswa yang sudah terbiasa mandiri dalam sikap maupun perbuatan akan mudah dalam pembelajaran, siswa yang memiliki sikap mandiri cenderung aktif dalam mengikuti kegiatan belajar dan berani untuk mengungkapkan pendapatnya.

Selain itu, Asrori (dalam Sultyaningsih, 2009: 34) mengungkapkan bahwa kurangnya kemandirian di kalangan peserta didik berhubungan dengan kebiasaan belajar yang kurang baik dimana siswa yang memiliki kemandirian belajar yang rendah cenderung cuek dan tidak memerdulikan arahan dari guru saat mengajar dan sering kali tidak memerdulikan tugas-tugas yang diberikan oleh guru seperti siswa sering ribut di dalam kelas, membolos, menyontek, tidak mengerjakan tugas dan mencari bocoran pada saat ujian.

Dalam proses pembelajaran, kemandirian harus dimiliki setiap siswa dengan adanya kemandirian yang tertanam dalam diri, siswa akan mudah dalam menyelesaikan setiap permasalahan dalam belajar karena itu, belajar harus bisa mandiri tanpa mengandalkan bantuan dari orang lain dan tidak menggantungkan belajar hanya dari guru, karena guru hanya berperan sebagai fasilitatos sehingga guru bukanlah satu-satunya sumber ilmu dan dapat mempergunakan berbagai sumber dan media untuk belajar.

Berdasarkan fenomena yang ditemukan di SMP Negeri 1 Bondoala, dimana siswa belum sepenuhnya memiliki kemandirian dalam belajar yang ditunjukkan dengan adanya siswa yang kedapatan berada di luar kelas saat jam belajar, menyontek saat ulangan dan tidak aktif saat kegiatan belajar mengajar, hal serupa diungkapkan oleh guru mata pelajaran, saat guru memberikan tugas untuk dikerjakan di rumah mereka cenderung mengerjakan di sekolah dan mengandalkan jawaban dari teman dan seringkali mencontek pada saat ulangan dan tidak aktif saat kegiatan belajar maupun kegiatan diskusi. Selain itu hal ini juga diperkuat dengan pemberian angket screening kepada siswa terkait dengan masalah kemandirian belajar di SMP Negeri 1 Bondoala. Peneliti membagikan angket screening pada 45 orang siswa. Berdasarkan angket screening diperoleh data bahwa ada beberapa siswa yang memiliki kemandirian belajar rendah.

Kemandirian dalam belajar perlu ditingkatkan, karena jika tidak segera ditangani proses belajar siswa akan tidak berjalan secara efektif yang akan berdampak pada nilai dan kebiasaan belajar siswa, oleh karena itu 
dibutuhkan penanganan yang efektif, salah salah satunya melalui layanan bimbingan dan konseling di sekolah. Layanan bimbingan dan konseling merupakan salah satu komponen pendidikan. Pelayanan bimbingan dan konseling merupakan usaha pemberian bantuan kepada siswa dalam mengembangkan kehidupan pribadi, karir, sosial, maupun belajar yang diberikan oleh tenaga profesional (Konselor/ Guru Bimbingan dan Konseling) dengan menggunakan layanan-layanan bimbingan dan konseling dan kegiatan pendukung.

Berdasarkan permasalahan kemandirian belajar yang ditemukan di SMP Negeri 1 Bondoala, salah satu langkah pemecahan masalah adalah dengan menggunakan layanan bimbingan kelompok. Prayitno dan Amti (2015: 116) mendefiniskan layanan bimbingan kelompok adalah layanan yang diberikan kepada sejumlah siswa dengan memanfaatkan dinamika. Kelompok terdiri atas seorang konselor atau lebih dan konseli sebagai anggota kelompok. Selanjutnya, Sukardi (2003: 48) mengemukakan bahwa layanan bimbingan kelompok yaitu layanan yang memungkinkan sejumlah individu secara bersama sama memeroleh berbagai bahan dari narasumber terutama dari konselor yang berguna untuk menunjang kehidupannya seharihari sebagai individu, pelajar, anggota keluarga dan anggota masyarakat serta untuk dasar pertimbangan dalam pengambilan keputusan.

Upaya yang dilakukan guru pembimbing untuk mengatasi perilaku kemandirian belajar siswa yang rendah hanya berupa teguran atau nasihat dan hal tersebut tidak berpengaruh pada perubahan kemandirian belajar siswa, untuk itu dalam penelitian ini peneliti menggunakan layanan bimbingan kelompok untuk mempengaruhi kemandirian belajar siswa. Tujuan peneliti menggunakan layanan ini karena permasalahan bukan hanya dialami oleh satu siswa tetapi beberapa orang siswa. Layanan ini efektif digunakan pada siswa yang jumlahnya relatif banyak, selain itu bimbingan kelompok bersifat multi arah adanya timbal balik antara konselor dengan konseli sehingga setiap anggota kelompok dapat saling berinteraksi untuk memecahkan suatu permasalahan dengan menyatukan jawaban dari masing masing anggota kelompok yang nantinya diharapkan setelah pemberian layanan bimbingan kelompok kemandirian belajar siswa dapat meningkat.
Berdasarkan latar belakang yang telah diuraikan di atas, maka peneliti tertarik untuk mengadakan penelitian yang berjudul "Pengaruh Layanan Bimbingan Kelompok Terhadap Kemandirian Belajar Siswa SMP Negeri 1 Bondoala". Tujuan penelitian ini adalah untuk mengetahui apakah terdapat pengaruh layanan bimbingan kelompok terhadap kemandirian belajar siswa di SMP Negeri 1 Bondoala.

\section{Kemandirian Belajar}

Sriyono (2015: 22) mengemukakan kemandirian belajar yaitu adanya aktifitas belajar yang diatur oleh diri sendiri, kesadaran diri dan bersifat mandiri atau mengatur kebutuhan sendiri tanpa bergantung pada orang lain sebagai sumber belajar dalam menyelesaikan permasalahan belajarnya. Selanjutnya, Gea (dalam Sriyono, 2015: 26) mendefiniskan kemandirian belajar adalah situasi yang memungkinkan seseorang memperoleh pengetahuan dan pemahaman serta keterampilan atas prakarsa atau inisiatif dan kemampuan sendiri yang didukung karena adanya motivasi, inisiatif, keyakinan, kepercayaan diri serta konsep diri positif yang memberikan peluang untuk meningkatkan hasil belajar.

Sriyono (2015: 26-28) menjelaskan beberapa hal yang memengaruhi kemandirian belajar siswa yaitu:

\section{Faktor internal}

Faktor internal adalah faktor yang berasal dalam diri indvidu seperti intelegensi, bakat dan kemampuan. Seseorang yang memunyai intelegensi yang tinggi terutama intelegensi belajar dapat beraktiftas dalam belajar secara efektif.

\section{Faktor Eksternal}

Faktor ekternal adalah faktor yang berasal dari luar diri individu yang terdiri dari beberapa yaitu:

a. Keluarga merupakan lingkungan pertama dan utama dalam kehidupan anak tempat ia belajar sebagai individu sosial dalam berinteraksi dengan kehidupan keluarganya, pengalaman interaksi dalam keluarga turut menentukan perilakunya di kemudian hari.

b. Lingkungan sekolah, sekolah merupakan penyelenggara pendidikan yang mencakup pengajaran, pelatihan dan bimbingan. Sekolah bukan hanya berperan 
memberikan pengetahuan, tetapi lebih dari itu peran guru selain mengembangkan kemampuan akademik siswa juga berperan membimbing siswa agar mau mandiri dalam belajar.

c. Lingkungan masyarakat, budaya di dalam masyarakat memberikan pengaruh terhadap cara berpikir, cara bersikap dan cara berperilaku seseorang, apabila lingkungan memberikan banyak pengaruh positif maka hal tersebut akan berpengaruh baik terhadap kemandirian belajar seseorang sebaliknya lingkungan yang kurang baik maka hal itu dapat memberikan dampak negatif terhadap kemandirian siswa.

Ciri-ciri kemandirian belajar

Gea (dalam Suid dan Syafrina, 2017: 72) mengatakan individu dikatakan mandiri apabila memiliki ciri- ciri sebagai berikut:

1. Percaya diri adalah meyakini pada kemampuan dan penilaian diri sendiri dalam melakukan tugas dan dapat memilih pendekatan yang efektif.

2. Mampu bekerja sendiri adalah usaha yang dilakukan secara mandiri untuk menghasilkan sesuatu yang membanggakan atas kesungguhan dan keyakinan yang dimiliki dalam diri.

3. Menguasai keahlian dan keterampilan yang sesuai dengan kerjanya, yaitu memunyai keterampilan sesuai dengan potensi yang diharapkan pada lingkungan kerjanya.

4. Mengatur waktu, yaitu kemampuan dalam mengatur jadwal sehari hari yang diprioritaskan dalam kegiatan yang bermanfaat.

5. Tanggung jawab adalah segala sesuatu yang harus dijalankan atau dilaksanakan oleh seseorang dalam melaksanakan sesuatu yang sudah menjadi pilihannya atau dengan kata lain tanggung jawab merupakan sebuah amanat atau tugas dari seseorang yang dipercayakan untuk menjaganya.

Selanjutnya, Sanan dan Yamin (dalam Sobri dan Moerdiyanto, 2014: 50) menambahkan secara singkat bahwa anak yang mandiri memiliki ciri-ciri, antara lain: 1) percaya pada kemampuan diri sendiri, 2) memiliki motivasi intriksir atau dorongan untuk bertindak yang berasal dari dalam diri individu, 3) dapat mengatur waktunya secara efisien, 4) bertanggung jawab atau menerima konsekuensi terhadap resiko atau tindakannya dan 5) tidak bergantung pada orang lain.

Dimensi kemandirian belajar

Tahar (2006: 94) menyatakan bahwa dalam sintesis kemandirian belajar terdapat dimensi pengelolaan belajar, tanggung jawab dan pemanfaatan berbagai sumber belajar, sebagai berikut:

1. Dimensi pengelolaaan belajar berarti peserta didik harus mampu mengatur strategi, waktu dan tempat untuk melakukan aktivitas belajarnya seperti membaca, meringkas, membuat catatan dan mendegarkan materi dari audio. Pengelolaan belajar itu sangat penting, peserta didiklah yang secara otonom menentukan strategi belajar yang digunakan, kapan ia menggunakan waktu belajarnya dan dimana ia melakukan proses pembelajarannya tanpa diperintah oleh orang lain. Kemampuan mengelola proses pembelajaran dapat membantu peserta didik untuk berhasil dalam belajar

2. Dimensi tanggung jawab berarti peserta didik mampu menilai aktivitas, mengatasi kesulitan dan mengukur kemampuan yang diperoleh dari belajar. Dalam belajar mandiri peserta didik dituntut untuk memiliki kesiapan, keuletan dan daya tahan. Sehingga diperlukan motivasi belajar yang tinggi. Kesulitan yang dialami dalam belajar harus mereka atasi sendiri dengan mendiskusikan sesama peserta ajar dengan memanfaatkan sumber belajar yang terkait dengan bahan ajar dan memperbanyak latihan sosial yang dapat meningkatkan pemahaman peserta ajar. Disamping itu, peserta ajar harus mengukur kemampuan yang diperoleh dari hasil belajar bila hasil belajarnya tidak memuaskan dengan memperbaiki cara belajar dan secara rutin mengerjakan latihan soal.

3. Dimensi pemanfaatan berbagai sumber belajar berarti peserta didik dapat menggunakan berbagai sumber belajar. Peserta didik secara leluasa menentukan piihan sumber belajar yang diinginkan. Kebebasan peserta didik dalam memilih berbagai sumber belajar diharapkan dapat memperkaya pemahaman terhadap bahan ajar. 
Bimbingan Kelompok

Prayitno dan Amti (2015: 308) mendefiniskan layanan bimbingan kelompok adalah layanan yang diberikan pada sekelompok orang dengan memanfaatkan dinamika kelompok. Selanjutnya, Gazda (dalam Prayitno, 2015: 309) mengemukakan bahwa bimbingan kelompok merupakan suatu kegiatan informasi yang bersifat personal, vokasional dan sosial bertujuan untuk membantu siswa dalam menyusun rencana dan pengambilan keputusan.

Pendapat lain mengenai bimbingan kelompok dijelaskan oleh Tohirin (2007:170) yang mengemukakan bahwa layanan bimbingan kelompok adalah upaya pemberian bantuan (bimbingan) kepada individu (siswa) melalui kegiatan kelompok. Dalam layanan bimbingan kelompok, aktivitas dan dinamika kelompok harus diwujudkan untuk membahas berbagai hal yang berguna bagi pengembangan dan pemecahan masalah individu atau siswa yang menjadi peserta layanan.

Tujuan Layanan Bimbingan Kelompok

Prayitno (dalam Fijriani dan Amaliawati, 2017: 25) mengemukakan bahwa tujuan bimbingan kelompok yaitu:

1. Mengembangkan kemampuan sosialisasi siswa, khususnya kemampuan komunikasi siswa.

2. Membahas topik topik tertentu yang mengandung permasalahan aktual dan menjadi perhatian siswa.

3. Melalui dinamika kelompok yang intensif, pembahasan topik topik itu mendorong pengembangan perasaan, pikiran, persepsi, wawasan dan sikap yang menunjang diwujudkannya tingkah laku yang lebih efektif.

\section{Metode Penelitian}

Penelitian ini dilaksanakan di SMP Negeri

1 Bondola selama kurang lebih 4 bulan yang dimulai sejak tanggal 19 Januari sampai dengan tanggal 8 Mei 2019. Perlakuan (treatment) dalam penelitian ini dilaksanakan selama 6 kali pertemuan dengan rincian dua kali dalam seminggu, lamanya tiap pertemuan 2 x 60 menit.

Jenis dan desain penelitian ini adalah pra eksperimen. Dengan menggunakan desain onegroup pre test-post test yang merupakan desain eksperimen yang hanya menggunakan satu kelompok subjek serta melakukan pengukuran sebelum dan sesudah pemberian perlakuan pada subjek. Perbedaan kedua hasil tersebut, dianggap sebagai efek perlakuan (Latipun, 2015: 81).

Sasaran penelitian ini terkait dengan permasalahan kemandirian belajar siswa yang rendah dan tindakan yang dilakukan terhadap permasalahan tersebut adalah dengan pemberian layanan bimbingan kelompok pada 8 orang subjek penelitian dengan menggabungkan 6 orang siswa yang memiliki kemandirian belajar rendah dan 2 orang siswa yang memiliki kemandirian belajar tinggi. Adapun karateristik subjek penelitian adalah:

1. Subjek penelitian ditentukan berdasarkan skor hasil pre test atau skoring

2. Subjek penelitian ini adalah siswa SMP Negeri 1 Bondoala yang memeroleh skor tertinggi pada angket perilaku kemandirian belajar rendah

3. Mendapat peresetujuan untuk menjadi subjek penelitian dari guru BK dan wali kelas

4. Siswa bersedia menjadi bagian dari kelompok untuk menjadi subjek penelitian.

Variabel dalam penelitian ini terdiri atas dua yakni kemandirian belajar sebagai variabel terikat (dependent) dan bimbingan kelompok sebagai variabel bebas (independent).

Tehnik pengumpulan data yang digunakan untuk memperoleh data adalah:

1. Wawancara. Pedoman wawancara yang dimaksud dalam penelitian ini adalah intrumen yang dibuat peneliti untuk mengarahkan wawancara agar tidak melebar kepada hal-hal yang tidak berhubungan dengan rancangan penelitian.

2. Angket Screening. Angket screening digunakan untuk memilih karakteristik siswa yang memiliki kemandirian belajar rendah untuk dijadikan subjek penelitian

3. Skala kemandirian belajar. Skala disusun berdasarkan indikator dari ciri-ciri kemandirian belajar. Skala yang akan digunakan terlebih dahulu diuji coba untuk mengetahui kriteria yag telah ditetapkan dalam penelitian ilmiah yaitu validitas dan reliabilitas. Dalam skala kemandirian belajar responden diberi alternatif jawaban yaitu empat alternatif pilihan Pernyataan positif SS (Sangat sesuai), S (Sesuai), Pertanyaan negatif TS (tidak sesuai), STS (Sangat tidak sesuai). Tehnik yang digunakan dalam peskoran yaitu Skala 
likert yang digambarkan dalam tabel berikut:

Dalam rangka mencari item yang memenuhi syarat validitas maka uji validitas pada instrumen penelitian ini akan menggunakaan bantuan program komputer Statical Packages For Social Science (SPSS) versi 15.0 diperoleh $\mathrm{r}_{\text {hitung }}$ dan kemudian dibandingkan dengan $r_{\text {tabel, }}$, Jika $r_{\text {hitung }} \geq r_{\text {tabel }}$ maka data tersebut dikatakan valid dan jika $r_{\text {tabel }} \geq r_{\text {hitung }}$ maka data tersebut invalid

Reliabilitas alat ukur untuk menentukan baik hasilnya pengukuran dengan alat tersebut dan dapat dipercaya. Sumanto (2014: 81) menjelaskan bahwa reliabilitas adalah tingkatan pada suatu tes secara konsisten mengukur berapapun hasil pengukuran itu. Reliabilitas dinyatakan dengan angka-angka biasanya sebagai suatu koefisien, koefisien dapat diterima ditentukan oleh jenis tes. Uji reliabilitas dihitung dengan program SPSS ( Statistical Packages Social Science) versi 15.0 dengan menggunakan rumus Alpha Cronbach.

Dalam penelitian ini peneliti menggunakan analisis deskriptif persentase untuk menjelaskan hasil perhitungan skor pretest (tes awal) dan post-test (tes akhir) yang dikonversikan ke dalam empat kategori penilaian yang terdiri atas sangat tinggi, tinggi, rendah dan sangat rendah.

Analisis statistik inferensial digunakan untuk menguji hipotesis penelitian. Penguji hipotesis dilakukan dengan menggunakan statistika non parametic yaitu dengan uji wicolxon signed rank untuk melihat ada tidaknya perbedaan gain score antara pre test dan post test pada kelompok eksperimen. Hal ini bertujuan untuk mengetahui perbedaan skor kemandirian belajar siswa pada saat sebelum diberikan perlakuan (pre test) dan sesudah diberikan perlakuan (Sugiyono, 2014)

\section{Hasil Penelitian dan Pembahasan \\ Hasil Penelitian}

Gambaran kemandirian belajar siswa kelas VIII ${ }^{2}$ SMP Negeri 1 Bondoala sebelum diberikan perlakuan (treatment) dapat diketahui berdasarkan hasil pengisian skala kemandirian belajar sebagaimana data yang disajikan pada tabel berikut:
Tabel 1

Skor Pre Test Sebelum Diberikan Layanan Bimbingan Kelompok

\begin{tabular}{|c|c|c|c|c|c|}
\hline No & Nama & JK & Skor & $\%$ & Kategori \\
\hline 1 & ER & $\mathrm{L}$ & 120 & $60 \%$ & Rendah \\
\hline 2 & $\overline{\mathrm{SL}}$ & $\bar{P}$ & 116 & $58 \%$ & Rendah \\
\hline 3 & $\overline{\mathrm{DS}}$ & $\mathrm{L}$ & 102 & $51 \%$ & Rendah \\
\hline 4 & GS & $\mathrm{P}$ & 112 & $56 \%$ & Rendah \\
\hline 5 & $\overline{\mathrm{DA}}$ & $\mathrm{P}$ & 110 & $55 \%$ & Rendah \\
\hline 6 & $\mathrm{D}$ & $\mathrm{P}$ & 148 & $74 \%$ & Tinggi \\
\hline 7 & $\mathrm{DW}$ & $\mathrm{P}$ & 166 & $83 \%$ & Sangat Ting \\
\hline 8 & II & $\mathrm{L}$ & 100 & $50 \%$ & Rendah \\
\hline \multicolumn{3}{|c|}{ Jumlah } & 974 & $487 \%$ & \multirow{2}{*}{ Rendah } \\
\hline \multicolumn{3}{|c|}{ Rata-Rata } & 121,75 & $60.88 \%$ & \\
\hline
\end{tabular}

Berdasarkan data pada Tabel 1 tersebut, siswa kelas VIII $^{2}$ SMP Negeri 1 Bondoala sebelum diberi perlakuan (pre test) termasuk dalam kategori rendah. Hal ini dapat dilihat dari rata-rata persentase kemandirian belajar siswa mencapai $60,88 \%$ dari 8 orang subjek penelitian.

Gambaran kemandirian belajar siswa kelas VIII ${ }^{2}$ di SMP Negeri 1 Bondoala setelah diberi perlakuan berupa layanan Bimbingan kelompok dapat diketahui berdasarkan hasil analisis angket kemandirian belajar siswa sebagaimana yang tertera pada tabel berikut ini:

Tabel 2

Skor Post Test Siswa Setelah Diberi Layanan Bimbingan Kelompok

\begin{tabular}{|c|c|c|c|c|c|}
\hline No & Nama & JK & Skor & $\%$ & Kategori \\
\hline 1 & D & $\mathrm{P}$ & 170 & $85 \%$ & Sangat Tinggi \\
\hline 2 & $\overline{\mathrm{DA}}$ & $\bar{P}$ & 157 & $78 \%$ & Tinggi \\
\hline 3 & DS & $\mathrm{L}$ & 140 & $70 \%$ & Tinggi \\
\hline 4 & $\overline{D W}$ & $\mathrm{P}$ & 176 & $88 \%$ & Sangat Tinggi \\
\hline 5 & ER & $\mathrm{L}$ & 164 & $82 \%$ & Tinggi \\
\hline 6 & GS & $\mathrm{P}$ & 154 & $77 \%$ & Tinggi \\
\hline 7 & Ii & $\mathrm{L}$ & 136 & $68 \%$ & Tinggi \\
\hline 8 & $\mathrm{SL}$ & $P$ & 160 & $80 \%$ & Tinggi \\
\hline \multicolumn{3}{|c|}{ Jumlah } & 1257 & $628 \%$ & \multirow{2}{*}{ Tinggi } \\
\hline \multicolumn{3}{|c|}{ Rata-Rata } & $\overline{157,13}$ & $78,5 \%$ & \\
\hline
\end{tabular}

Berdasarkan data yang tertera pada tabel di atas, skor kemandirian belajar siswa kelas VIII $^{2}$ SMP Negeri 1 Bondoala setelah diberi perlakuan (post test) mengalami perubahan dari kategori rendah menjadi kategori tinggi. Hal ini dapat dilihat dari rata-rata persentase diperoleh mencapai $78,5 \%$ dari 8 orang subjek penelitian. 
Berdasarkan hasil analisis data yang telah disajikan, maka dapat diperoleh gambaran kemandirian belajar siswa kelas VIII SMP Negeri 1 Bondoala sebelum dan sesudah diberi perlakuan. Adapun hasil analisis data tersebut dapat dilihat pada tabel berikut ini:

\section{Tabel 3}

Perbandingan Skor Pre Test dan Post Test

\begin{tabular}{|c|c|c|c|c|c|c|c|}
\hline \multirow{2}{*}{ No } & \multirow{2}{*}{ Nama } & \multirow{2}{*}{ JK } & \multicolumn{2}{|c|}{ Skor $\%$} & \multicolumn{2}{|c|}{ Kategori } & Kenaikan \\
& & & Pre Test & Post Test & Pre Test & Post Test & \\
\hline 1 & D & P & $74 \%$ & $85 \%$ & Tinggi & $\begin{array}{c}\text { Sangat } \\
\text { Tinggi }\end{array}$ & $11 \%$ \\
\hline 2 & DA & P & $55 \%$ & $78 \%$ & Rendah & Tinggi & $23 \%$ \\
\hline 3 & DS & L & $51 \%$ & $70 \%$ & Rendah & Tinggi & $19 \%$ \\
\hline 4 & DW & P & $83 \%$ & $88 \%$ & Tinggi & $\begin{array}{c}\text { Sangat } \\
\text { Tinggi }\end{array}$ & $5 \%$ \\
\hline 5 & ER & L & $60 \%$ & $82 \%$ & Rendah & Tinggi & $22 \%$ \\
\hline 6 & GS & P & $56 \%$ & $77 \%$ & Rendah & Tinggi & $21 \%$ \\
\hline 7 & ii & L & $50 \%$ & $68 \%$ & Rendah & Tinggi & $18 \%$ \\
\hline 8 & SL & P & $58 \%$ & $80 \%$ & Rendah & Tinggi & $22 \%$ \\
\hline \multicolumn{2}{|c|}{ Jumlah } & $487 \%$ & $628 \%$ & Rendah & Tinggi & $141 \%$ \\
\hline \multicolumn{2}{|c|}{ Rata-Rata } & $60,88 \%$ & $78,5 \%$ & Rendah & Tinggi & $17,62 \%$ \\
\hline
\end{tabular}

Dari tabel di atas diketahui bahwa sebelum diberi perlakuan (pre test) tingkat kemandirian belajar siswa masuk dalam kategori rendah dengan skor persentase rata-rata $60,88 \%$. Setelah diberi perlakuan (post test) tingkat kemandirian belajar siswa berada dalam kategori tinggi dengan skor persentase rata-rata 78,5\%. $\mathrm{Hal}$ tersebut menunjukkan bahwa tingkat kemandirian belajar siswa SMP Negeri 1 Bondoala mengalami peningkatan yang berada dalam kategori tinggi sebesar $17,62 \%$ setelah diberi perlakuan berupa layanan bimbingan kelompok .

\section{Analisis statistik inferensial}

Analisis data ini dilakukan untuk mengetahui signifikansi pengaruh layanan bimbingan kelompok terhadap kemandirian belajar siswa kelas VIII SMP Negeri 1 Bondoala dilakukan analisis data Non Parametic dengan uji Wicolxon Signed Rank dengan menggunakan SPSS versi 15 . Hasil uji analisis statstik tersebut disajikan pada tabel berikut:
Tabel 4

Hasil Uji Wicolxon Signed Rank Test Statistics(b)

\begin{tabular}{|l|r|}
\hline & VAR00002- \\
& VAR00001 \\
\hline$Z$ & $-2,805(\mathrm{a})$ \\
Asymp. Sig. (2-tailed) &, 005 \\
\hline
\end{tabular}

a Based on negative ranks.

b Wilcoxon Signed Ranks Test

Berdasarkan analisis statistik inferensial dengan menggunakan uji wicolxon pada taraf signifikansi $\alpha=0,05$ diperoleh $\mathrm{P}_{\text {value }}=0,005$. $\mathrm{P}_{\text {value }}$ lebih kecil dari $\alpha(0,005<0,05)$ sehingga $\mathrm{H}_{\mathrm{a}}$ diterima. Hal ini berarti layanan bimbingan kelompok berpengaruh secara signifikan terhadap kemandirian belajar siswa.

\section{Pembahasan}

Penelitian ini bertujuan untuk mengetahui apakah layanan bimbingan kelompok dapat berpengaruh terhadap kemandirian belajar siswa SMP Negeri 1 Bondoala. Berdasarkan hasil analisis data dengan jumlah subjek sebanyak 8 siswa, dapat diketahui kemandirian belajar siswa sebelum diberi pelakuan (pre test) berupa layanan bimbingan kelompok berada pada kategori rendah yaitu sebesar $60,88 \%$ sehingga kemandirian belajar siswa perlu ditingkatkan. Untuk meningkatkan kemandirian belajar siswa maka peneliti memberikan perlakuan berupa layanan bimbingan kelompok.

Hasil penelitian ini memperkuat hasil penelitian yang dilakukan oleh Alexander (2017) tentang penggunaan layanan bimbingan kelompok untuk meningkatkan kemandirian belajar siswa kelas VII SMP Negeri 1 Kalianda Tahun Ajaran 2015/ 2016. Hasil penelitian tersebut menyimpulkan bahwa layanan bimbingan kelompok dapat berpengaruh terhadap kemandirian belajar siswa. Terdapat 12 orang subjek dalam hasil penelitian ini. Hasil analisis per individu berdasarkan hasil pre test rata rata persentasenya $57,6 \%$ atau berada dalam kategori rendah sedangkan setelah diberi perlakuan (post test) rata rata persentasenya menjadi $82,2 \%$ dan diketahui semua subjek mengalami peningkatan sebesar $31,80 \%$.

Layanan bimbingan kelompok adalah salah satu metode yang dapat digunakan terhadap kemandirian belajar siswa yang dalam prosesnya memanfaatkan dinamika kelompok 
untuk mencegah timbulnya suatu masalah yang dapat menjadi penghambat perkembangan individu dan berfungsi untuk mengembangkan potensi-potensi individu serta berguna membantu individu dalam pengambilan keputusan.

Tohirin (2007: 170) mengemukakan bahwa layanan bimbingan kelompok adalah upaya pemberian bantuan (bimbingan) kepada individu (siswa) melalui kegiatan kelompok, dalam layanan bimbingan kelompok, aktivitas dan dinamika kelompok harus diwujudkan untuk membahas berbagai hal yang berguna bagi pengembangan dan pemecahan masalah individu atau siswa yang menjadi peserta layanan.

Pelaksanaan layanan bimbingan kelompok terhadap kemandirian belajar siswa dilakukan sebanyak 6 kali pertemuan dengan durasi waktu 2 x 45 menit dan tiap pertemuan membahas satu topik materi berdasarkan indikator kemandirian belajar yang dikemukakan oleh Sanan dan Yamin (dalam Sobri dan Moerdiyanto, 2014: 50) bahwa siswa yang mandiri memiliki ciri-ciri percaya pada kemampuan diri sendiri, memiliki motivasi instrinsik yang berasal dari dalam diri, dapat mengatur waktu secara efisien, memiliki tanggung jawab atau menerima konsekuensi dari setiap tindakannya dan tidak bergantung pada orang lain. Kelima ciri-ciri tersebut menjadi topik materi dalam layanan bimbingan kelompok.

Setelah diberi perlakuan (treatment) berupa layanan bimbingan kelompok, siswa selanjutnya mengisi angket kemandirian belajar (post test) yang diberikan oleh peneliti. Tujuan pemberian post test adalah untuk mengetahui tingkat keberhasilan pemberian layanan bimbingan kelompok terhadap kemandirian belajar siswa. setelah diberi layanan bimbingan kelompok (post test), kemandirian belajar berada dalam kategori tinggi yaitu sebesar 78,5\%. Sehingga nampak adanya peningkatan kemandirian belajar siswa sebesar 17,62\%. Hal ini menunjukkan bahwa layanan bimbingan kelompok dapat berpengaruh terhadap kemandirian belajar siswa di SMP Negeri 1 Bondoala,

Salah satu yang menjadi penentu keberhasilan treatment yang diberikan yaitu adanya antusias siswa dalam mengikuti layanan dan komitmen dari setiap anggota kelompok untuk mengubah perilaku dan menerapkan apa yang telah diperoleh dalam bimbingan kelompok dapat diaplikasikan dalam kegiatan belajar maupun dalam kehidupan sehari-hari. Perubahan perilaku tanpa disadari secara langsung oleh beberapa siswa. Siswa yang awalnya pasif dalam kegiatan layanan secara bertahap menjadi aktif, dimulai dari diam, siswa mulai menjawab walaupun terbata-bata dan siswa mulai terlihat antusias dalam mengikuti layanan seperti siswa sudah mulai berani memberikan komentar dan saran terhadap apa yang sedang dibahas.

Pada awal pertemuan walaupun siswa belum sepenuhnya memahami mengenai kemandirian belajar namun setelah pemberian penguatan dan materi secara bertahap pada tiap tiap pertemuan siswa sudah mulai memahami akan pentingnya sikap mandiri di dalam proses belajar yang harus dimiliki setiap siswa dan untuk mencapai tujuan belajar siswa dituntut aktif sebagai individu mandiri yang mampu menyelesaikan setiap permasalahan belajar yang dialaminya tanpa harus bergantung pada orang lain.

Sriyono (2015) mengemukakan bahwa dengan berbekal kemandirian dalam diri siswa, akan mendorong mereka melakukan sesuatu yang lain sebagai suatu karakter atau kepribadian. Siswa yang memunyai kemandirian tingkat kemandirian tinggi akan merasa puas dan bangga apabila oleh diri sendiri tanpa bergantung pada orang lain.

\section{Kesimpulan dan Saran Kesimpulan}

Berdasarkan hasil analisis terhadap data penelitian, gambaran skor kemandirian belajar siswa sebelum diberi perlakuan berupa layanan bimbingan kelompok, skor pre test termasuk dalam kategori rendah yaitu $60,88 \%$ sedangkan setelah diberi layanan bimbingan kelompok skor hasil post test kemandirian belajar siswa meningkat menjadi $78,5 \%$. Hal tersebut menunjukkan bahwa pengaruh layanan bimbingan kelompok mampu meningkatkan kemandirian belajar siswa sebesar 17,62\%. Selain itu, hasil analisis inferensial dengan menggunakan uji wicolxon signed rank dengan taraf signifikansi $\alpha=0,05$ dan diperoleh $\mathrm{P}_{\text {value }}=$ 0,005 yang berarti $\mathrm{P}_{\text {value }}<\alpha(0,005<0,05)$ maka $\mathrm{H}_{\mathrm{a}}$ diterima dan $\mathrm{H}_{\mathrm{o}}$ ditolak, sehingga layanan bimbingan kelompok berpengaruh terhadap kemandirian belajar siswa. 


\section{Saran}

1. Bagi Sekolah. Peneliti memberikan layanan bimbingan kelompok di ruangan kelas sehingga menganggu siswa yang lain yang bukan dari subjek penelitian karena harus meninggalkan ruang kelas. Hal tersebut disebabkan karena ruang guru BK yang relatif sempit dan kurang kondusif sebagai sarana dalam pelaksanaan layanan bimbingan kelompok. Sekolah semestinya memerhatikan kondisi ruang BK agar bisa lebih memadai sehingga pelaksanaan layanan bimbingan dan konseling dapat berjalan efektif.

2. Bagi Guru BK. Berdasarkan wawancara dengan guru BK diketahui bahwa jika dalam mengentaskan permasalahan siswa, guru BK hanya memberikan sanksi berupa teguran maupun punishment kepada siswa. Dalam hal ini guru BK diharapkan dapat menggunakan layanan bimbingan dan konseling yang lebih bervariasi dalam membantu siswa menyelesaikan permasalahannya khususnya permasalahan kemandirian belajar siswa, Salah satu layanan bimbingan dan konseling yang dapat digunakan adalah layanan bimbingan kelompok

3. Bagi Siswa, siswa perlu mengaplikasikan apa yang telah diperoleh dalam pelaksanaan layanan bimbingan kelompok agar kemandirian belajarnya lebih maksimal dan siswa diharapkan dapat mengembangkan pemahamannya mengenai fungsi dari bimbingan dan konseling dan dapat memanfaatkan BK dalam membantu mereka menangani setiap permasalahannya yang dimilikinya.

4. Bagi Peneliti lanjutan. Penelitian ini dilaksanakan hanya sebatas untuk mengetahui apakah layanan bimbingan kelompok dapat berpengaruh terhadap kemandirian belajar siswa. Pemberian layanan bimbingan kelompok hanya diberikan dalam kurun waktu yang singkat, oleh karena itu diperlukan rancangan tindakan yang tepat dan efektif agar dapat meningkatkan kemandirian belajar siswa tanpa ada aspek yang terlewatkan.

\section{Daftar Pustaka}

Alexander, Muhamad Fiqri. (2017). Penggunaan Layanan Bimbingan Kelompok Untuk Meningkatkan Kemandirian Belajar
Siswa SMP Negeri 1 Kalianda Kabupaten Lampung. Skripsi. Universitas Lampung.

Fijriani dan Rediska Amaliawati. (2017). Layanan Bimbingan Kelompok Dalam Meningkatkan Komunikasi Interpersonal Siswa. Jurnal Universitas Indraprasta PGRI Jakarta. Vol 1. No 1.

Latipun. (2015). Psikologi Eksperimen. Malang: UMM Press.

Prayitno dan Erman Amti. (2015). Dasar Dasar Bimbingan dan Konseling. Jakarta: PT Rineka Cipta.

Sugiyono. (2014). Metode Penelitian Kuantitatif. Jakarta: Rineka Cipta.

Sultyaningsih. (2009). Kemandirian dan Prestasi Belajar Matematika SMP Negeri 1 Purworejo. Skripsi. Universitas Muhamadiyah Purworejo.

Sumanto. (2014). Teori dan Aplikasi Metode Penelitian. Jakarta: PT Buku Seru.

Sobri, Muhamad dan Moerdiyanto. (2014). Pengaruh Kedisiplinan dan Kemandirian Belajar Terhadap Hasil Belajar Ekonomi Madrasah Aliyah di Kecamatan Praya. Jurnal Universitas Negeri Yogyakarta. Vol 1. No.1.

Sriyono, Heru. (2015). Bidang Bimbingan Belajar (Program Bimbingan Belajar Untuk Meningkatkan Kemandirian Belajar). Depok: PT Raja Grafindo Persada.

Sukardi, Dewa Ketut. (2003). Manajemen Bimbingan dan Konseling Di Sekolah. Bandung: CV Alfabeta.

Syafrina, Alfiati dan Suid. (2017). Analisis Kemandirian Siswa Dalam Proses Pembelajaran. Jurnal Univeritas Syiah Kuala Banda Aceh. Vol. 1. No. 5.

Tahar, Irzan. (2006). Hubungan Kemandirian Belajar dan Hasil Belajar Pada Pendidikan jarak Jauh.. Jurnal Pendidikan Vol 7. No. 2. 
Tohirin. (2007). Bimbingan dan Konseling di Sekolah dan Madrasah. Jakarta: PT Raja Grafindo Persada. 